\title{
Cuban Exogenous Pulmonary Surfactant in Treatment of Pediatric Acute Respiratory Distress Syndrome
}

\author{
Valentín S. Rodríguez-Moya MD PhD, María del Carmen Machado-Lubián MD MS, Yinet Barrese-Pérez MS, \\ Yisel Ávila-Albuerne MS, Rolando Uranga-Piña MS, Odalys Blanco-Hidalgo PhD, Elaine Díaz-Casañas PhD
}

\begin{abstract}
INTRODUCTION Acute respiratory distress syndrome is a complex heterogeneous disorder with low incidence but high case fatality in children. Treatment with pulmonary surfactants is a possible option. Surfacen, a Cuban exogenous pulmonary surfactant, has been proven safe and effective in premature newborns with hyaline membrane disease, but evidence regarding its efficacy in older children is still inconclusive.
\end{abstract}

OBJECTIVE Determine Surfacen's efficacy in improving oxygenation and increasing survival in children with acute respiratory distress syndrome.

METHODS A multicenter (five pediatric intensive care units in four provinces), open-label, controlled, randomized phase III clinical trial with two treatment groups was conducted from November 2009 through August 2013, with 19 girls and 23 boys aged 1 month to 18 years. The experimental group (20 patients) received conventional treatment (oxygenation and mechanical ventilation) plus intratracheal instillation of Surfacen $(100 \mathrm{mg} / 4 \mathrm{~mL}$ ) every eight hours for three days. The control group (22 patients) received only conventional treatment. The primary dependent outcome was patient vital status (alive or deceased) 28 days after study enrollment. Other variables and outcomes analyzed were age, sex, ARDS presentation, Kirby index (arterial oxygen tension over inspired oxygen fraction), oxygenation index, static lung compliance, transcutaneous oxygen saturation, radiographic course, mechanical ventilation time and length of stay in neonatal intensive care. Statistical tests used were the chi-square test and Fisher exact test.

RESULTS On day 28 , there was $80 \%$ survival in the experimental group versus $38.1 \%$ in the control group. There were significant differences between the experimental and the control group in Kirby index, oxygenation index, static lung compliance and radiographic course, all favoring the experimental group. For every 2.38 patients treated in total, there was one additional survivor in the experimental group.

CONCLUSIONS When combined with conventional therapy in the regimen employed, Surfacen improves oxygenation and increases survival in children with ARDS.

KEYWORDS Exogenous pulmonary surfactant, acute pulmonary distress syndrome, ARDS, children, intensive care, Cuba

\section{INTRODUCTION}

Acute respiratory distress syndrome (ARDS) is a complex heterogeneous disorder that involves severe progressive refractory hypoxemia and has various causes. ARDS may be pulmonary (severe pneumonia, radiation pneumonitis, bronchial aspiration of stomach contents, pulmonary contusion, inhalation of toxic gases, oxygen toxicity) or extrapulmonary (sepsis, septic shock, nonpulmonary trauma, acute pancreatitis, pesticide poisoning, multiple transfusions of blood and blood products, and intracranial hypertension).[1] ARDS is an unresolved health problem associated with sepsis and multiple organ failure:[1] Nearly 50 years after Ashbaugh described it,[2] ARDS case fatality in children is still $30 \%-40 \%$. Ventilation with positive end-expiratory pressure (PEEP) is the fundamental and most important treatment strategy.[1,3,4]

Exogenous surfactants have been used to treat ARDS in several clinical trials,[5-7] all of which reported better lung function, reflected in improved oxygenation. Willson found a significant reduction in mortality, although not in ventilation time, length of stay, or time in intensive care.[7] Although results are promising, surfactant use in children needs rigorous evaluation, since there is no consensus among pediatricians on treatment regimen dosage and frequency. $[1,5]$ Surfactant effects are short-lived because of inhibition by plasma proteins, which has led to the idea that small, repeated doses could be more effective than a single dose. It is imperative that more clinical trials be conducted with exogenous surfactants.[1]

In 1995, Cuba's State Regulatory Authority for Drugs Medical Equipment and Devices (CECMED) approved use of the natural porcine surfactant Surfacen, developed in Cuba. Since it received CECMED registration (0800), Surfacen has become part of standard medical treatment of hyaline membrane disease in preterm newborns in all neonatal intensive care units (NICU),[8-10] which has helped lower Cuba's infant mortality rate due to this cause.[11]

Surfacen has pharmacologic and biophysical properties that may stop ARDS or at least mitigate the complex inflammatory oxidizing process involved in its pathophysiology.[12] In planning this clinical trial, we posited that adding Surfacen to conventional treatment with oxygenation and mechanical ventilation should increase efficacy in terms of oxygenation recovery and survival in children with ARDS.

\section{METHODS}

Study type, patients and sample A phase III, nationwide, multicenter clinical trial was conducted at five pediatric hospitals in four provinces in central and eastern Cuba: two in Santiago de Cuba (Dr Antonio María Béguez César Pediatric Hospital and Dr Juan de la Cruz Martínez Maceira Children's Teaching Hospital), one in Holguín (Octavio de la Concepción y la Pedraja Provincial Pediatric Teaching Hospital), one in Camagüey (Dr Eduardo Agramonte Piña Provincial Pediatric Teaching Hospital) and another in Villa Clara (José Luis Miranda Provincial Pediatric Teaching Hospital). The trial was open-label and controlled, with randomization into two treatment groups (experimental and control), and was conducted from November 2009 through August 2013.

Sample size calculation We considered observed case fatality the main dependent outcome. Because ARDS is rare, we used a two-stage sequential design that called for stopping the study as early as possible to compare the two rates and test the hypothesis that expected case fatality would be higher in the control 
group. We set expected case fatality at $70 \%$ for the control group and $40 \%$ for the experimental group, based on Surfacen's excellent biophysical properties and anti-inflammatory effects. Type I and type II errors were calculated in $\mathrm{R}$ and preset as $\mathrm{a}$ and $\mathrm{b}$ values not to exceed limits of $6 \%$ and $20 \%$, respectively. Based on these calculations, we confirmed that 18 patients per group would be sufficient in both the first and second stages. This design allowed us to optimize the study so that it could be stopped in the first stage, should there be early evidence of a positive effect of Surfacen on survival. This was possible because the sample size per group was larger than planned $(>18)$ at the time of the first cut, and the difference in observed response rates exceeded the boundary value. The sequential method's flexibility[13-15] allows sample size cuts that do not necessarily coincide with planned sample size when there is evidence of an effect, as long as type one error is sequentially controlled.

A randomization list was created by hospital and blocks of four (random sequences of two symbols, with each symbol occurring twice), using a table of random numbers from a uniform probability density function in the interval $(0,1)$, generated with Statistica 5.5. This method ensured totally random patient assignment to the groups. Treatment assignment was conducted using sealed envelopes, each containing a card identifying the assigned treatment, labeled with a patient code. This method ensured that clinical investigators did not know a given patient's assigned treatment group until the decision to initiate treatment was made.

The sample comprised 42 children. For two of them, the only data available came from the initial assessment and the exit point. One had been assigned to the experimental group but died before treatment began; the other was assigned to the control group but no longer met all selection criteria, so assessments were terminated. However, they were counted as study patients, because no withdrawal criteria had been set; i.e., all available data were processed.

Inclusion criteria Patients were selected who were aged 1 month to 18 years, diagnosed with ARDS according to the criteria of the 1994 American-European Consensus Conference on ARDS,[16] and whose parents gave written consent for participation.

Exclusion criteria Patients with blood diseases, cancer, congenital cardiopathy with increased pulmonary flow or signs of pulmonary hypertension, or known hypersensitivity to Surfacen were excluded.

Treatment groups There were 20 patients assigned to the experimental group and 22 to the control group. Patients in the first group received conventional treatment plus Surfacen (see below), and those in the control group received only conventional treatment. In both groups, as oxygenation improved, controlled respiratory assistance levels were modified to prevent ventilatorinduced injury.

Variables Demographic variables were age (grouped in years: $<1$, $1-5,6-10,>10)$ and sex (female, male). Clinical outcomes were selected according to guidance issued by the European Medicines Evaluation Agency.[17] The main dependent outcome was patient vital status (alive or deceased) 28 days after randomization.
ARDS presentation Clinical forms were classified as pulmonary (pneumonia, bronchial aspiration, pulmonary contusion, inhalation of toxic gases, near-drowning, mechanical airway obstruction and others) and extrapulmonary (sepsis, septic shock, nonpulmonary trauma, pancreatitis, extracorporeal circulation or cardiopulmonary bypass, thromboembolism, fat embolism, drug overdose, congenital diaphragmatic hernia, burns, multiple transfusions, electrocution, anaphylaxis, typhoid fever, hypereosinophilic syndrome).

Gasometric and ventilatory variables PEEP was obtained from the preset value on the mechanical ventilator (normal value 2-5 $\mathrm{cm} \mathrm{H}_{2} \mathrm{O}$ ). Maximum PEEP was obtained from the preset value on the mechanical ventilator and stratified into values of $6-10 \mathrm{~cm}$ $\mathrm{H}_{2} \mathrm{O}, 11-15 \mathrm{~cm} \mathrm{H}_{2} \mathrm{O}, 16-20 \mathrm{~cm} \mathrm{H}_{2} \mathrm{O}$ and $>20 \mathrm{~cm} \mathrm{H}_{2} \mathrm{O}$. Inspired oxygen fraction $\left(\mathrm{FiO}_{2}\right)$ was also obtained from the preset value on the mechanical ventilator (normal $<60 \%$ ).

Arterial oxygen tension $\left(\mathrm{PaO}_{2}\right)$ was obtained from arterial blood gas results (normal 95-100 mmHg). Arterial carbon dioxide tension $\left(\mathrm{PaCO}_{2}\right)$ was also obtained from arterial blood gas testing (normal 35-45 mmHg).

Kirby index $\left(\mathrm{PaO}_{2} / \mathrm{FiO}_{2}\right)$ is a direct indicator of clinical progress in ARDS. We defined clinical progress and patient responsiveness by values of $\geq 200$.

Oxygenation index $(\mathrm{Ol})$ was calculated as mean airway pressure $x \mathrm{FiO}_{2} \times\left(100 / \mathrm{PaO}_{2}\right)($ normal <5).

Static lung compliance (SLC) was calculated as (exhaled tidal volume/plateau pressure) minus PEEP (normal 1-2 mL/kg weight/ $\mathrm{cm} \mathrm{H}_{2} \mathrm{O}$ ).

Transcutaneous oxygen saturation $\left(\mathrm{SaO}_{2}\right)$ was obtained from finger pulse oximetry (normal 95\%-100\%).

Radiographic course was classified as improved, stable or worse, depending on the reduction, persistence or increase, respectively, in pulmonary lesions observed in chest radiography.

Hospital outcomes Mechanical ventilation time was defined as days between intubation at time of ARDS diagnosis and extubation. Length of stay in pediatric intensive care unit (PICU) was defined as days from date of admission with ARDS until discharge from PICU.

Control treatment The conventional ARDS treatment protocol was used in participating hospitals' PICUs:

- pressure-controlled ventilation

- hypercapnia permitted up to $80 \mathrm{mmHg}$

- tidal volumes close to physiologic values for age and body weight $(5-7 \mathrm{~mL} / \mathrm{kg})$ in patients with respiratory system compliance, and stable volumes of 3-6 mL/kg in patients with poor lung compliance

- inspiration: expiration ratio from 1:2 to 2:1

- $\mathrm{pH}>7.2$

- PEEP above the lower inflection point of the pressure/volume curve by static maneuvers, and sufficient to keep $\mathrm{PaO}_{2}$ above $60 \mathrm{mmHg}$ in arterial blood gas-if PEEP value revealed falling pulse oximetry saturation or the static compliance curve 
showed signs of alveolar overcompliance compromising the patient's hemodynamics, recommended measures were initiated until full stabilization was achieved.

- $\mathrm{FiO}_{2}$ high enough to ensure $\mathrm{SaO}_{2}$ of $88 \%-90 \%$.[16]

Investigational treatment The surfactant used in this trial was Surfacen, a porcine pulmonary surfactant produced and sold by Cuba's National Center for Agricultural Health in collaboration with the National Biopreparations Center. It is supplied as a sterile white lyophilized product in a $6 \mathrm{R}$ vial containing $50 \mathrm{mg}$ total phospholipids. It is composed of phospholipids (95\%), mainly dipalmitoylphosphatidylcholine; hydrophobic proteins (SP-B and SP-C, 1.5\%); and other lipids (3.5\%).[18] Its anti-inflammatory and antibacterial effects have been shown in both in vitro and in vivo models, $[19,20]$ as have its excellent biophysical properties.[12] Toxicology studies have shown that it is nontoxic.[21] The safety of Surfacen has been proven, its safety profile similar to that of other internationally marketed surfactants. No adverse reactions to Surfacen have occurred in any clinical trials. $[7,8,22,23]$

This consisted of conventional treatment plus intratracheal instillation of $100 \mathrm{mg}$ of Surfacen diluted in $4 \mathrm{~mL}$ of water for injection $(25 \mathrm{mg} / \mathrm{mL})$, every 8 hours for 3 days, until 9 doses were completed. This low dose was used because there is no consensus on optimal dose, and because using amounts in keeping with those prescribed for newborns would involve intrapulmonary administration of a fluid volume $(120 \mathrm{~mL}$ for a child weighing $30 \mathrm{~kg}$ ) that would flood the alveoli, negatively affect gas exchange, and obstruct the airway. In addition, there are indications that what characterizes patients with ARDS is a change in phospholipid profile, not in total amounts of phospholipids.[24] In a phase II clinical trial of Surfacen in adult ARDS patients, repeated doses of $100 \mathrm{mg}$ produced a significant improvement in oxygenation.[25]

Radiographic monitoring After diagnosis of ARDS, chest $x-$ rays were performed on the first three days and on the fifth day after enrollment. During daily rounds, PICU specialists assessed all x-rays to date as a set. Findings were then summarized by radiologists in written reports. Results were compared to initial x-rays to assess changes, if any, in amounts of inflammatory infiltrates in lung fields, to classify radiographic course.

Data collection and analysis All data were recorded in the study patients' medical records and case report forms, and entered into a database for statistical processing. Available data were used for patients who died before completing all protocol assessments, so that some analyses did not include all patients who started the study.

Processing and statistical analysis used the significance threshold and power set during sample size determination ( $5 \%$ significance threshold and $81.7 \%$ power).

The main analysis of efficacy was a one-tailed test comparing the percentage of surviving patients in the two groups 28 days after enrollment. We chose a one-tailed test because of ARDS' low incidence and high case fatality, and based in earlier results, we expected that, even with a small sample size, Surfacen would have a positive effect on survival, and in no case would have a negative effect.

In the experimental group, treatment efficacy was assessed one hour and eight hours after each dose of Surfacen. In the control group, assessments were performed at the same intervals following initial assessment, which included arterial blood gas testing and mechanical ventilation settings.

Normality tests were conducted to confirm t-test requirements. When necessary, we used a Mann-Whitney-Wilcoxon ranksum test, a nonparametric t-test substitute that has the advantage of not depending on an assumption of normal distribution. For quantitative variables, we calculated descriptive statistics (means and censored and uncensored medians, the latter with confidence intervals and standard deviations), overall and for each treatment group. Qualitative variables were summarized as absolute and relative frequencies.

The Fisher exact test was used to confirm the assumption of independence in $2 \times 2$ contingency tables. Confidence intervals were estimated for differences between proportions and odds ratios, using the normal approximation to the binomial distribution. The chi-square test for independence versus homogeneity was used with $n \times 2$ contingency tables. The Mann-Whitney-Wilcoxon ranksum test was used instead of chi square if cell sample sizes were small.

Number needed to treat was used to interpret the survival table for each treatment group. Log-rank analysis was used to compare survival curves.

Data processing was performed using SAS for Windows 9.1.3. Windows SPLUS 6.2 was used to generate graphics. Differences were considered statistically significant when $p$ was $<0.05$.

Ethics The research protocol and supplemental documentation were designed following the specifications of the Guidelines for Good Clinical Practice in Cuba[26] and the Ethical Principles for Medical Research Involving Human Subjects (Declaration of Helsinki), amended by the 64th World Medical Association General Assembly, 2013.[27] Participating hospitals' ethics committees approved the study protocol (reflected in Cuba's Public Registry of Clinical Trials, RPCEC00000163).[28] Patient enrollment began once CECMED authorized the study.[29] Legal representatives (parents or guardians) provided written consent after being given oral and written information about the study in the presence of a witness.

\section{RESULTS}

Table 1 displays experimental and control group demographics and initial values for clinical variables, demonstrating that the groups were substantially similar. Most patients were infants aged less than one year, and pulmonary forms of ARDS predominated. In some patients, more than one cause was reported at enrollment: pneumonia (30 patients; 14 in the experimental group and 16 in the control group), sepsis (29 patients; 15 experimental and 14 control), septic shock (22 patients; 11 in each group) and bronchial aspiration (one patient in the experimental group). 
Table 1: Clinical and demographic characteristics of patients at enrollment

\begin{tabular}{|c|c|c|c|c|}
\hline \multirow[t]{2}{*}{ Variable } & & $\begin{array}{l}\text { Experimental group } \\
\qquad(n=20)\end{array}$ & $\begin{array}{l}\text { Control group } \\
\quad(n=22)\end{array}$ & $\begin{array}{l}\text { Total } \\
(n=42)\end{array}$ \\
\hline & & n (\%) & $\mathrm{n}(\%)$ & $n(\%)$ \\
\hline \multirow{4}{*}{$\begin{array}{l}\text { Age (years) } \\
p=0.4429\end{array}$} & $<1$ & $12(60.0)$ & $9(40.9)$ & $21(50.0)$ \\
\hline & $1-5$ & $5(25.0)$ & $8(36.4)$ & $13(31.0)$ \\
\hline & $6-10$ & 0 & $4(18.2)$ & $4(9.5)$ \\
\hline & $>10$ & $3(15.0)$ & $1(4.5)$ & $4(9.5)$ \\
\hline \multirow{2}{*}{$\begin{array}{l}\text { Sex } \\
p=0.9764\end{array}$} & Female & $9(45.0)$ & $10(45.4)$ & $19(45.2)$ \\
\hline & Male & $11(55.0)$ & $12(54.5)$ & $23(54.8)$ \\
\hline \multirow{2}{*}{$\begin{array}{l}\text { ARDS presentation } \\
p=0.3706\end{array}$} & Pulmonary & $15(75.0)$ & $16(72.7)$ & $31(73.8)$ \\
\hline & Extrapulmonary & $5(25.0)$ & $6(27.3)$ & $11(26.2)$ \\
\hline $\begin{array}{l}\text { Initial Kirby index } \\
p=0.2786\end{array}$ & Mean (SD) & $102.09(44.8)$ & $110.20(42.3)$ & \\
\hline
\end{tabular}

on initial clinical assessment, but differences were seen starting from first day that Surfacen was initiated. Kirby index surpassed 200 by the fourth dose (at 32 hours) in the experimental group and remained $>200$ thereafter (Figure 2).

Radiographic findings in the two groups were similar on the first day following treatment initiation $(p=0.8072)$ (data unavailable for 2 patients who died in the first 24 hours). Progression of pulmonary infiltrates was seen in $59 \%$ of all patients (23/39); 33.3\% (13/39) showed no change; and $7.7 \%(3 / 39)$ showed radiographic improvement (Table 4). Subsequent assessments found significantly better progress in the experimental than in the control group.
Efficacy Table 2 displays analysis of the main dependent outcome, based on 41 patients for whom information was available. Survival in the experimental group was $80 \%(16 / 20)$ and $38.1 \%$ $(8 / 21)$ in the control group. For every 2.38 patients treated, one additional survivor was obtained in the experimental group. Uncensored median survival was greater in the experimental group than in the control group (34 days versus 12 days, $p=0.013$ logrank test). Figure 1 shows the survival curve for the experimental group, which remained above that of the control group through day 28 after enrollment. It should be noted that two patients (one in each group) died after the final date set in the protocol for assessing this outcome.

When we reviewed autopsy results to analyze cause of death (Table 2) and possible associations with the investigational drug, Surfacen, we confirmed that no death was caused by its use. All deaths were explained by patient clinical condition and underlying disease.

There were significant differences between the treatment groups concerning changes in gasometric and ventilatory outcomes, all favoring the experimental group (Table 3). There was no difference in Kirby index $(p=0.2786)$ between the two groups
Hospital indicators showed no differences between the two groups. Mean mechanical ventilation time was 13.8 days in the experimental group and 14.1 in the control group ( $p=0.2364)$. Mean PICU stay was 16.1 days in the experimental group and 15.2 in the control group $(p=0.3008)$.

The percentage of patients in the experimental group who responded to treatment (according to the Kirby index) was $75 \%$ $(15 / 20)$ and $23.8 \%(5 / 21)$ in the control group. This difference was significant ( $p<0.001$ Fisher exact test). The probability of response in the experimental group was 3.1 times ( $\mathrm{Cl} 95 \% 1.5-7.4)$ that of the control group.

\section{DISCUSSION}

Age distribution of patients enrolled in this study was similar to that of other studies, $[6,30]$ in which the highest percentage of patients with ARDS fell in the group aged $<5$ years, especially the group aged $<1$ year. This may be linked to immaturity of the immune system at these ages, with resulting deficiencies in lactoferrin, lysozyme, defensins, collectins and immunoglobulin $A$, as well as mucociliary clearance abnormalities, which makes these patients more susceptible to serious infections.[1]
Table 2: Patient vital status on day $28^{*}$ and causes of death

\begin{tabular}{|c|c|c|c|c|c|c|}
\hline \multirow{4}{*}{$\begin{array}{l}\text { Age group } \\
\text { (years) }\end{array}$} & \multicolumn{4}{|c|}{ Treatment group } & \multirow{2}{*}{\multicolumn{2}{|c|}{ Total }} \\
\hline & \multirow{2}{*}{\multicolumn{2}{|c|}{$\begin{array}{c}\text { Experimental } \\
\text { Vital status }\end{array}$}} & \multicolumn{2}{|c|}{ Control } & & \\
\hline & & & Vital : & status & \multicolumn{2}{|c|}{ Vital status } \\
\hline & $\begin{array}{l}\text { Alive } \\
\text { n (\%) }\end{array}$ & $\begin{array}{c}\text { Deceased } \\
\mathrm{n}(\%)\end{array}$ & $\begin{array}{l}\text { Alive } \\
\text { n (\%) }\end{array}$ & $\begin{array}{c}\text { Deceased } \\
\text { n (\%) }\end{array}$ & $\begin{array}{l}\text { Alive } \\
\text { n (\%) }\end{array}$ & $\begin{array}{c}\text { Deceased } \\
\text { n (\%) }\end{array}$ \\
\hline$<1(n=20)$ & $11(91.7)$ & $1(8.3)$ & $2(25.0)$ & $6(75.0)$ & $13(65.0)$ & $7(35.0)$ \\
\hline $1-5(n=13)$ & $3(60.0)$ & $2(40.0)$ & $5(62.5)$ & $3(37.5)$ & $8(61.5)$ & $5(38.5)$ \\
\hline $6-10(n=4)$ & 0 & 0 & $1(25.0)$ & $3(75.0)$ & $1(25.0)$ & $3(75.0)$ \\
\hline$>10(n=4)$ & $2(66.7)$ & $1(33.3)$ & 0 & $1(100.0)$ & $2(50.0)$ & $2(50.0)$ \\
\hline Total $(n=41)$ & $16(80.0)$ & $4(20.0)$ & $8(38.1)$ & $13(61.9)$ & $24(58.5)$ & $17(41.5)$ \\
\hline \multicolumn{7}{|c|}{ Cause of death per autopsy } \\
\hline MOF & & $1(25.0)$ & & $2(15.4)$ & & $3(17.6)$ \\
\hline ARDS & & $3(75.0)$ & & $10(76.9)$ & & $13(76.5)$ \\
\hline Septic shock & & 0 & & $1(7.7)$ & & $1(5.9)$ \\
\hline Total & & $4(100.0)$ & & $13(100.0)$ & & $17(100.0)$ \\
\hline
\end{tabular}

${ }^{*} p=0.0074$ (Fisher exact test)

MOF: multiple organ failure
The predominance of pulmonary ARDS is consistent with similar studies that describe pneumonia and sepsis as the most common presentations.[1,7,19] Clinical trials with various exogenous surfactants[6,9,31] have shown that better response was achieved in patients with direct lung injury than in those with systemic disease. This can be explained by the fact that in systemic injury, the alveolarcapillary membrane allows plasma proteins and fatty acids to enter. Moreover, endothelial injury causes disorganized release of lytic enzymes, oxygen free radicals and nitrogenated species. These effects of endothelial injury inactivate endogenous surfactant and serve as a substrate for bacterial ischemia, reperfusion and translocation mechanisms during the course of ARDS.[31]

Achieving oxygenation stability during the first few days of ARDS is a challenge for clinical in- 
Figure 1: Survival curve by treatment group

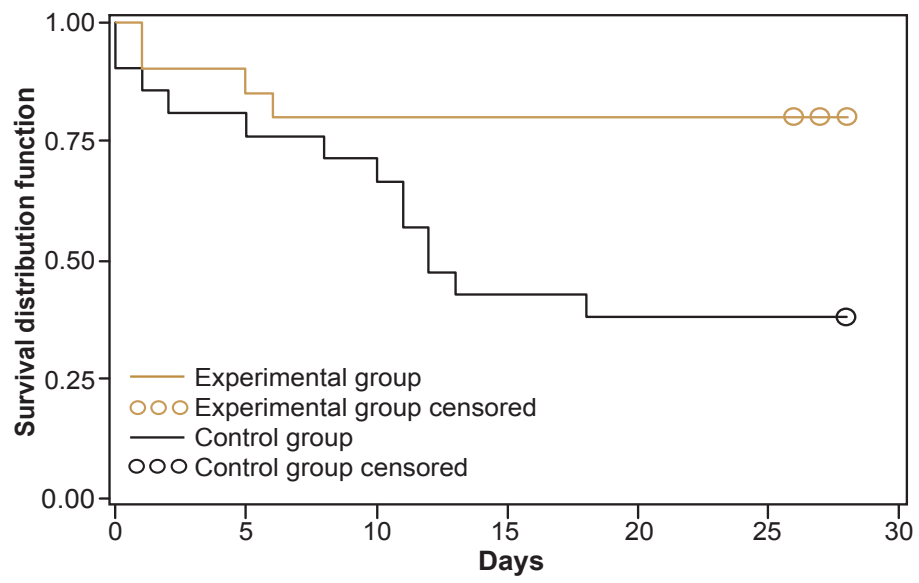

Table 3: Changes in gasometric and ventilatory indicators by treatment group

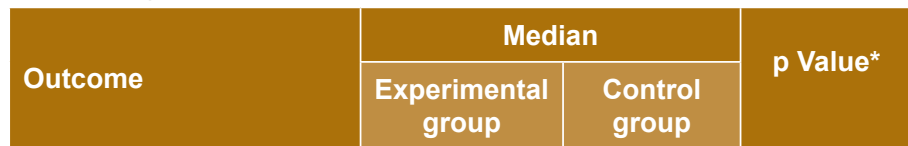

\begin{tabular}{|l|r|r|r|}
\hline Maximum PEEP $\left(\mathrm{cm} \mathrm{H}_{2} \mathrm{O}\right)$ & $6-10$ & $11-15$ & 0.0370 \\
\hline $\mathrm{FiO}_{2}(\%)$ & 50.0 & 100.0 & 0.0014 \\
$\mathrm{PaO}_{2}(\mathrm{mmHg})$ & 151.1 & 93.82 & 0.0068 \\
\hline $\mathrm{PaCO}_{2}(\mathrm{mmHg})$ & 49.23 & 57.6 & 0.0349 \\
\hline $\mathrm{Kirby}$ index & 303.0 & 107.5 & $<0.001$ \\
\hline $\mathrm{SaO}(\%)$ & 96.5 & 91.0 & 0.0038 \\
\hline $\mathrm{SLC}\left(\mathrm{mL} / \mathrm{cm} \mathrm{H}_{2} \mathrm{O}\right)$ & 11.1 & 5.2 & 0.0067 \\
\hline $\mathrm{OI}$ & 4.7 & 20.1 & $<0.001$ \\
\hline
\end{tabular}

*Wilcoxon test

OI: oxygenation index

$\mathrm{PaO}_{2}$ : arterial oxygen tension

$\mathrm{SaO}_{2}$ : transcutaneous oxygen saturation SLC: static lung compliance

Figure 2: Kirby index ${ }^{*}$ at time of treatment administration

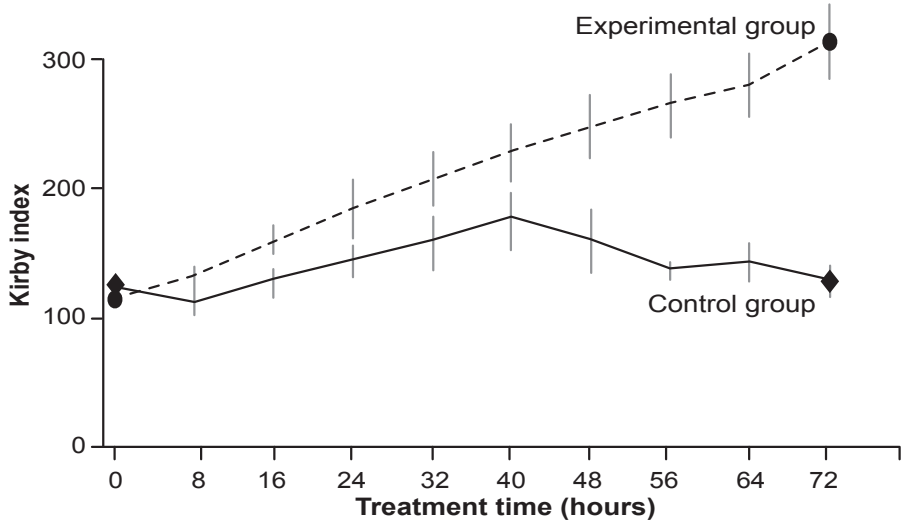

*arterial oxygen tension/inspired oxygen fraction

vestigators, in our study reflected in the fact that most deaths occurred in the first few days after patient enrollment, regardless of randomization group.

Our results suggest that Surfacen has a positive impact on ARDS survival. Reports from other studies of surfactants and ARDS survival are contradictory, with some indicating that surfactant treatment increases survival, $[7,32]$ and others finding no effect.[19,33]
Table 4: Radiologic course by treatment group and response

\begin{tabular}{|c|c|c|c|c|c|}
\hline \multirow[b]{2}{*}{ Day } & \multirow[b]{2}{*}{ Condition } & \multicolumn{2}{|c|}{ Treatment group } & \multirow{2}{*}{$\begin{array}{l}\text { Total } \\
\text { n }(\%)\end{array}$} & \multirow{2}{*}{$\begin{array}{c}\text { p Value } \\
X^{2}\end{array}$} \\
\hline & & $\begin{array}{c}\text { Experimental } \\
n(\%)\end{array}$ & $\begin{array}{c}\text { Control } \\
n(\%)\end{array}$ & & \\
\hline \multirow{4}{*}{1} & Improved & 2 (10.5) & $1(5.0)$ & $3(7.7)$ & \multirow{3}{*}{0.8072} \\
\hline & Stable & $6(31.6)$ & $7(35.0)$ & $13(33.3)$ & \\
\hline & Worse & $11(57.9)$ & $12(60.0)$ & $23(59.0)$ & \\
\hline & Total & $19(100.0)$ & $20(100.0)$ & $39(100.0)$ & \\
\hline \multirow{4}{*}{$2^{a}$} & Improved & $12(70.6)$ & $1(5.6)$ & $13(37.1)$ & \multirow{3}{*}{$<0.001$} \\
\hline & Stable & $4(23.5)$ & $9(50.0)$ & $13(37.1)$ & \\
\hline & Worse & $1(5.9)$ & $8(44.4)$ & $9(25.7)$ & \\
\hline & Total & $17(100.0)$ & $18(100.0)$ & $35(99.9)^{b}$ & \\
\hline \multirow{4}{*}{$3^{c}$} & Improved & $13(76.5)$ & 2 (12.5) & $15(45.5)$ & \multirow{3}{*}{$<0.001$} \\
\hline & Stable & $4(23.5)$ & $5(31.3)$ & $9(27.3)$ & \\
\hline & Worse & 0 & $9(56.3)$ & $9(27.3)$ & \\
\hline & Total & $17(100.0)$ & $16(100.0)$ & $33(100.1)^{b}$ & \\
\hline \multirow{4}{*}{5} & Improved & $14(82.4)$ & $4(25.0)$ & $18(54.5)$ & \multirow{3}{*}{0.0037} \\
\hline & Stable & $1(5.9)$ & $2(12.5)$ & $3(9.1)$ & \\
\hline & Worse & $2(11.8)$ & $10(62.5)$ & $12(36.4)$ & \\
\hline & Total & $17(100.1)^{b}$ & $16(100.0)$ & $33(100.0)$ & \\
\hline
\end{tabular}

aOn day 2, 2 patients died in each group. ${ }^{\mathrm{b}}$ Rounding error

'On day 3, 2 patients died in the control group.

Overall case fatality in our study is consistent with reports from other countries that it is $\geq 50 \%$, regardless of treatment strategy. $[34,35]$ Exceptionally, Willson reports overall case fatality of approximately $25 \%$.[7]

A recent paper reported no significant difference in case fatality for patients randomized to a group that received a combination of conventional therapy plus the surfactant Lucinactant, versus control patients who received only conventional treatment. Lucinactant is a synthetic surfactant, however,[36] unlike Surfacen.

Some authors posit that ARDS case fatality is due to hypoxemic injury, which causes irreversible deterioration of the respiratory cell unit, leading to the need for a respiratory support and mechanical ventilation to prolong life; in this conception, ARDS fits the category of multiple organ failure triggered by decreased tissue oxygen availability, leading to cell injury and ultimately, organ failure.[37-40]

Combining Surfacen with conventional treatment was effective because it increased arterial blood oxygenation in patients treated at the dose and frequency used. This is consistent with radiographic course, in which we noted considerable improvement in the number of collapsed areas of laminar or total atelectasis with no gas exchange,[10,41] as well as decreased inflammation in experimental group patients. Willson and Notter's review of the topic states that lung aeration changes are clear in x-rays, and reflect improved oxygenation associated with administration of exogenous pulmonary surfactant.[32]

While earlier oxygenation assessments showed no significant differences between the treatment groups, differences in $\mathrm{OI}$ and SLC were seen after the fourth assessment, which is consistent with hemodynamic stabilization in the experimental group. The treatment model of repeated low doses also improved $\mathrm{PaO}_{2}$ and $\mathrm{FiO}_{2}$ values, a basic indicator of survival. Other authors have obtained similar results, finding evidence that exogenous surfactants have a positive effect on oxygenation.[5,6,31,42] 
$\mathrm{PaO}_{2}$ and $\mathrm{SaO}_{2}$ value improvements resulted from reestablishment of alveolar oxygenation functions in the experimental group. These functions are associated with a significant decrease in $\mathrm{FiO}_{2}$, which help prevent oxygen toxicity and allow improved recovery compared to control patients treated with high oxygen levels for longer periods.[34,35]

PEEP has been used to improve arterial oxygenation for over two decades.[3,4] PEEP levels in patients in the experimental group were significantly lower than in the control group, from which we can infer that Surfacen achieves alveolar recruitment and opens collapsed alveolar populations, as well as keeping alveoli open longer, as evidenced by increased SLC and OI and decreased $\mathrm{FiO}_{2}$. Several authors agree that determining optimal PEEP is not simple, and advocate more for individualized treatment, with high PEEP when lung injury in the exudative phase allows recruitment, and low PEEP for very stiff lungs in the fibrotic stage, to prevent airspace collapse and alveolar shear stress phenomena. $[1,43-45]$

Improvements in Kirby index, OI and SLC are evidence of treatment effectiveness in increasing oxygenation.[1] By the second day of treatment, there were already significant differences between the study groups for these indicators, demonstrating that the investigational treatment was more effective than conventional treatment. Patients in the experimental group reached levels close to physiologic values, unlike in the control group, where there were indications of stabilization, but not improvement. The Kirby index and $\mathrm{Ol}$ are the indicators most often used to evaluate effectiveness of exogenous surfactants, regardless of the age group in which they are administered, since this ratio changes due to lung dysfunction and several ventilatory variables.[32]

The significantly better radiographic progress in the investigational group was an unexpected result, given the slow rate of change in this outcome and the fact that a clinical trial of Surfacen in adult ARDS found no differences in radiographic course between groups.[25] Nevertheless, it is plausible. The function of pulmonary surfactant is to achieve alveolar interdependence (through the biophysical characteristics of the surfactant, which lowers surface tension in the collapsed area, causing simultaneous and equal expansion of all recruited alveoli), preventing some alveoli from inflating while others remain collapsed.[12,46] This is why the radiographic course for patients in the experimental group changed beginning on the second day of treatment, along with improvements in compliance and oxygenation index. Radiographic improvement is associated with recovery in the atelectasic areas, which causes radiopaque areas to become transparent, reflected in notable improvements in both clinical status and oxygenation gasometry.

The immunomodulatory,[21] antibacterial[22] and biophysical[12] properties of the surfactant used in this study contributed to improved lung function. This was due to its alveolar stabilizing effect, through reducing capillary-alveolar edema, and its demonstrated antibacterial effect on gram-positive and gram-negative microorganisms that cause deterioration of lung parenchyma.[22]

Hospital indicators (mechanical ventilation time and PICU stay) are outcomes assessed in many clinical trials with pulmonary surfactants. There is a wide variety of results, and as with other outcomes, they depend on dosage, treatment regimen, route of administration, type of surfactant, and ARDS etiology, among other factors.[32,35,47]

In his meta-analysis, Duffett found that pulmonary surfactant therapy was significantly associated with reduced case fatality and shorter mechanical ventilation time, although no differences were found in PICU stay.[48] Hong found a significant reduction in both mechanical ventilation time and PICU length of stay.[49] Our results are more in keeping with those of Thomas, who found no decrease in duration of mechanical ventilation.[36]

Our small sample size is a fundamental but unavoidable limitation, due to the high mortality of the disease. Even with this small sample, our results support the efficacy of Surfacen in this context, and CECMED has therefore approved the use of Surfacen in children with ARDS as a new therapeutic indication, after assessing all documentation generated in the clinical trial.[21]

\section{CONCLUSIONS}

Our results suggest that combining Surfacen with conventional therapy in the treatment regimen used improves oxygenation and increases survival in children with ARDS.

\section{ACKNOWLEDGMENTS}

The authors thank the researchers and PICU nursing staff who participated in this trial. $-1 /$ -

\section{REFERENCES}

1. Pediatric Acute Lung Injury Consensus Conference Group. Pediatric acute respiratory distress syndrome: consensus recommendations from the Pediatric Acute Lung Injury Consensus Conference. Pediatr Crit Care Med. 2015;16(5 Suppl 1):428-39.

2. Ashbaugh DG, Bigelow DB, Petty TL, Levine $\mathrm{BE}$. Acute respiratory distress in adults. Lancet [Internet]. 1967 Aug 12 [cited 2016 Jan 12];290(7511):319-23. Available from: http:// www.sciencedirect.com/science/article/pii/ S0140673667901687

3. Hodgson CL, Tuxen DV, Davies AR, Bailey MJ, Higgins $A M$, Holland $A E$, et al. A randomised controlled trial of an open lung strategy with staircase recruitment titrated PEEP and targeted low airway pressures in patients with acute respiratory distress syndrome. Crit Care [Internet] 2011[cited 2016 Apr 27];15(3):R133. Available from: http://www.biomedcentral.com/content/pdf/ cc10249.pdf

4. García-Fernández J, Canfrán S, Gómez de Segura IA, Suárez-Sipmann F, Aguado D, Hedenstierna G. Pressure safety range of barotrauma with lung recruitment manoeuvres. Eur J Anaesthesiol [Internet]. 2013 Sep [cited 2016 Apr 27];30(9):567-74. Available from: http:// journals.Iww.com/ejanaesthesiology/Abstract /2013/09000/Pressure_safety_range_of_baro trauma_with_lung.9.asp $\bar{x}$

5. Raghavendran K, Willson D, Notter RH. Surfactant therapy of ALI and ARDS. Crit Care Clin [Internet]. 2011 Jul 1[cited 2016 Jan 12];27(3):525-59. Available from: http://www .ncbi.nlm.nih.gov/pmc/articles/PMC3153076/

6. Willson DF, Thomas NJ, Tamburro R, Truemper R, Truwit J, Conaway M, et al. Pediatric Calfactant ${ }^{\circledR}$ in acute respiratory distress syndrome trial. Pedi- atr Crit Care Med [Internet]. 2013 Sep [cited 2016 Jan 12];14(7):657-65. Available from: http://www intensivo.sochipe.cl/subidos/catalogo3/Calfac tante\%20en\%20SDRA\%20PCCM\%202013.pdf

7. Willson DF, Thomas NJ, Markovitz BP, Bauman LA, DiCarlo JV, Pon S, et al. Effect of exogenous surfactant (Calfactant $\circledast$ ) in pediatric acute lung injury: a randomized controlled trial. JAMA [Internet]. 2005 Jan 26 [cited 2016 Apr 27];293(4):470-6. Available from: http://jama .jamanetwork.com/article. aspx?articleid $=200218$ \&resultclick=1

8. Moreno Vásquez $O$, Lee López M, Domínguez Dieppa F, Pascual López MA, Alonso Abad AL, Jiménez Rivero $G$, et al. Estudio de la eficacia del Surfacen $₫$ en el distress respiratorio del recién nacido. Rev Cubana Pediatr [Internet]. 1999 AprJun [cited 2016 Apr 27];71(2):60-71. Available from: http://scielo.sld.cu/scielo.php?script=sci 
_arttext\&pid=S0034-75311999000200002\&lng= es\&nrm=iso\&tlng=es. Spanish.

9. Morilla Guzmán AA, Díaz Casañas E, Debesa García F, Fernández Limia O. Efectividad del SURFACEN® en neonatos prematuros con síndrome de dificultad respiratoria. Rev Cubana Farm [Internet]. 2015 [cited 2016 Apr 27];49(3):502-11. Available from: http://scielo .sld.cu/pdf/far/v49n3/far10315.pdf. Spanish.

10. Morilla-Guzmán AA, Díaz-Casañas E, Fernández-Limia O, Ávila-Albuerne Y, Barrese-Pérez Y. Uso de surfactante porcino en recién nacidos pre términos con bronconeumonía de inicio temprano. Rev Arch Médico Camagüey [Internet] 2015 [cited 2016 Apr 27];19(4):[about 7 pages] Available from: http://www.revistaamc.sld.cu/ index.php/amc/article/view/3787. Spanish.

11. National Health Statistics and Medical Records Division (CU). Anuario Estadístico de Salud 2015 [Internet]. Havana: Ministry of Public Health (CU); 2016 [cited 2016 Sep 27]. 206 p. Available from: http://files.sld.cu/dne/files/2016/04/Anuario 2015_electronico-1.pdf. Spanish.

12. Blanco-Hidalgo O, Cruz-Rodríguez A, OspinaRamírez OL, López-Rodríguez E, VázquezMartínez L, Pérez-Gil J. Interfacial behavior and structural properties of a clinical lung surfactant from porcine source. Biochim Biophys Acta [Internet]. 2012 Nov [cited 2016 Apr 27];1818(11):2756-66. Available from: http:// www.sciencedirect.com/science/article/pii/ S0005273612002210

13. Lan KKG, DeMets DL. Discrete sequential boundaries for clinical trials. Biometrika [Internet]. 1983 Dec [cited 2017 Mar 8];70(3):659-63. Available from: http://eclass.uoa.gr/modules/ document/file.php/MATH301/PracticalSession3/ Lan_DeMets_1983.pdf

14. Jennison C, Turnbull BW. Group Sequential Methods with Applications to Clinical Trials. Boca Raton: Chapman and Hall/CRC; 1999 Sep 15. $416 \mathrm{p}$.

15. East-6, Statistical software for the design, simulation and monitoring clinical trials. User manual [Internet]. Cambridge: Cytel Inc.; 2016 [cited 2017 Mar 8]. Available from: http://www.cytel. com/software/east\#section east

16. Bernard GR, Artigas A, Brigham KL, Carlet J, Falke $\mathrm{K}$, Hudson L, etal. The American-European Consensus Conference on ARDS. Definitions, mechanisms, relevant outcomes, and clinical trial coordination. Am J Respir Crit Care Med [Internet]. 1994 Mar 1 [cited 2016 Jan 12];149 (3Pt 1):818-24. Available from: http://www.atsjournals.org/doi/abs/10.1164 ajrccm.149.3.7509706?url_ver=Z39.88-2003 \&rfr_id=ori:rid:crossref.org\&rfr_dat=cr_pub\%3 dpub̄med

17. European Agency for the Evaluation of Medicinal Products. CPMP/EWP/504/97. Committee fo proprietary medicinal products. Points to consider on clinical investigation of medicinal products in the treatment of patient with acute respiratory distress syndrome. London: European Agency for the Evaluation of Medicinal Products;1997.

18. Manzanares Tapia D, Díaz Casañas E, Alfonso Lorenzo WC, Escobar Medina AC, Colomé Dagnesses $\mathrm{H}$, Muñoz Pérez $\mathrm{MC}$, et al, inventors; Centro Nacional de Sanidad Agropecuaria, assignee. Surfactante pulmonar natural de origen porcino. Republic of Cuba patent CU A61K 35/42. 1997. Spanish.

19. Blanco-Hidalgo O, Beltrán-Núñez A, GonzálezRodríguez D, Sánchez-Calero J, Fernández-Limia O, Faure-García R, et al. Some Anti-Inflammatory Properties of a Natural Pulmonary Surfactant: SURFACEN ${ }^{\circledR}$. ACP. 2000;9(3):201-2.

20. Blanco-Hidalgo O, Riverón-Alemán Y, de ArmasSanabria E, Sánchez-Calero J, Faure-García R,
Fernández-Limia O SURFACEN® inhibe el crecimiento de bacterias causantes de infecciones respiratorias. Biotecnol Aplicada [Internet]. 2005 [cited 2016 Apr 27];22(4):279-81. Available from: http://elfosscientiae.cigb.edu.cu/PDFs/Biotec nol\%20Apl/2005/22/4/BA0022040C279-281 .pdf. Spanish.

21. National Drugs Quality Control Center (CU). Expediente de Registro Sanitario de Surfacen ${ }^{\circledR}$ (No. 0800). Obtenido en 1995; última renovación 2016. Havana: National Drugs Quality Contro Center (CU); 2016. Spanish.

22. Sánchez-Mendiola M, Martínez-Natera OC Herrera-Maldonado N, Ortega-Arroyo J. Estudio controlado del tratamiento de la enfermedad de membrana hialina del recién nacido pretérmino con surfactante pulmonar exógeno (porcino vs bovino). Gac Méd Mex [Internet] 2005 Jul-Aug [cited 2016 Apr 27];141(4):26771. Available from: http://www.scielo.org . $\mathrm{mx} / \mathrm{scielo} . \mathrm{ph} \mathrm{p}$ ? pid=S0016-3813200500 0400003\&script=sci arttext\&tIng=pt. Spanish.

23. Barrese Pérez $Y$, Hidalgo Sánchez AO, Albuerne Ávila Y, Uranga Piña R, Díaz Casañas E, Fernandez Limia O. Seguridad del tratamiento con surfactante pulmonar en el síndrome de dificultad respiratoria aguda en adultos. AMC [Internet]. 2015 [cited 2016 Apr 27];19(6):551-8. Available from: http://www.revistaamc.sld.cu/ index.php/amc/issue/view/88. Spanish.

24. Esteban A, Fernández-Segoviano $P$, FrutosVivar F, Aramburu JA, Nájera L, Ferguson ND, et al. Comparison of clinical criteria for the acute respiratory distress syndrome with autopsy findings. Ann Intern Med [Internet]. 2004 Sep 21 [cited 2016 Apr 27];141(6):440-5. Available from: https://www.researchgate.net/profile/ Niall_Ferguson/publication/8332494_Compari son_of_clinical_criteria_for_the_acute_respira tory distress_syndrome_with_autopsy_findings/ links/004635168343f05052000000.pdf

25. Barrese-Pérez $\mathrm{Y}$, Hidalgo-Sánchez AO, Albuerne-Ávila $Y$, Uranga-Piña R, Díaz-Casañas $E$, Fernández-Limia $O$. Surfactante pulmonar exógeno en adultos con síndrome de dificultad respiratoria aguda. Neumol Cir Torax [Internet] 2015 Jul-Sep [cited 2016 Apr 27];74(3):172-8. Available from: http://www.scielo.org.mx/scielo. php?script=sci arttext $\&$ pid=S0028-37462015 000300002\&lng=es\&nrm=iso\&tlng=es. Spanish.

26. Ministry of Public Health (CU); National Drugs Quality Control Center (CU). Directrices sobre Buenas Prácticas Clínicas en Cuba [Internet] Havana: ECIMED; 2000 [cited 2014 Aug 8] Available from: http://www.cecmed.cu/sites/ default/files/adjuntos/reglamentacion/Dir_BPC .pdf. Spanish.

27. World Medical Association. Declaración de Helsinki de la AMM. Principios éticos para las investigaciones médicas en seres humanos [Internet] Ferney-Voltaire (FR): World Medical Association 1964 Jun [cited 2014 Aug 8]. 9 p. Available from: http://www.isciii.es/ISCIII/es/contenidos/fd-inves tigacion/fd-evaluacion/fd-evaluacion-etica-in vestigacion/Declaracion-Helsinki-2013-Esp.pdf Spanish.

28. Cuban Public Registry of Clinical Trials [Internet]. Havana: National Clinical Trials Coordinating Center (CU); c2014. Evaluación de la eficacia y la seguridad del SURFACEN $₫$ en el tratamiento del Síndrome de Distress Respiratorio Agudo en edades pediátricas; 2016 Mar 29 [cited 2016 Aug 8]. Available from: http://rpcec .sld.cu/ensayos/RPCEC00000163-Sp/revisions/ view/2495/3688. Spanish.

29. National Drugs Quality Control Center (CU) Protocolo de Investigación de EC fase III "Evaluación de la eficacia y seguridad del Surfacén en el tratamiento del Síndrome de Distress
Respiratorio en edades pediátricas”. Aprobado por el CECMED, el 16/11/2009 con número de referencia 05.005.09.B. Havana: National Drugs Quality Control Center (CU); 2009 Nov. Spanish.

30. Garza Alatorre A, Hernández Rosales CD, Cantú Moreno D. Prevalencia del Síndrome de Dificultad Respiratoria Aguda en una unidad de cuidados intensivos pediátrica polivalente. Med Univ. 2012 Jan;14(54):11-5. Spanish.

31. Suresh GK, Soll RF. Pharmacologic Adjuncts II: Exogenous Surfactants. In: Goldsmith J, Karotkin $\mathrm{E}$, editors. Assisted Ventilation of the Neonate. St. Louis: Saunders-Elsevier Inc.; 2011. p. 371-88.

32. Willson DF, Notter RH. The future of exogenous surfactant therapy. Resp Care [Internet] 2011 Sep [cited 2016 Apr 27];56(9):1369-88. Available from: http://rc.rcjournal.com/content /56/9/1369

33. Spragg RG, Lewis JF, Walmrath HD, Johannigman J, Bellingan G, Laterre PF, et al. Effect of recombinant surfactant protein C-based surfactant on the acute respiratory distress syndrome. N Engl J Med [Internet]. 2004 Aug 26 [cited 2016 Apr 27];351(9):884-92. Available from: http:// discovery.ucl.ac.uk/8024/1/8024.pdf

34. Rojas Medina JE, León Villanueva A, Molano M. Síndrome de dificultad respiratoria aguda en pediatría. Acta Colombiana Cuidado Intensivo. 2010;10:213-26. Spanish.

35. Ríos-Meléndez NA, Garza-Alatorre A. Uso del surfactante en el síndrome de dificultad respiratoria aguda (SDRA) en pediatría. Med Univ. 2011 Jan;13(50):37-40. Spanish.

36. Thomas NJ, Guardia CG, Moya FR, Cheifetz IM, Markovitz B, Cruces $\mathrm{P}$, et al. A pilot, randomized, controlled clinical trial of lucinactant, a peptidecontaining synthetic surfactant, in infants with acute hypoxemic respiratory failure. Pediatr Crit Care Med [Internet]. 2012 Nov [cited 2016 Apr 27];13(6):646-53. Available from: https:// www.researchgate.net/profile/Pablo_Cruces/ publication/229082114_A_pilot_randomized controlled clinical trial of lucinactant a pepti de-containing_synthetic_surfactant_in_infants with_acute_hypoxemic_respiratory_failure/ links/00b49524862702cb76000000.pdf

37. Costa EL, Amato MB. The new definition for acute lung injury and acute respiratory distress syndrome: is there room for improvement? Curr Opin Crit Care [Internet]. 2013 Feb [cited 2016 Jan 12];19(1):16-23. Available from: http://journals.Iww.com/co-criticalcare/Abstract /2013/02000/The_new_definition for_acute_lung injury_and_acute.4.aspx

38. Rittayamai N, Brochard L. Recent advances in mechanical ventilation in patients with acute respiratory distress syndrome. Eur Respir Rev [Internet]. 2015 Mar [cited 2016 Apr 27];24(135):132-40. Available from: http://err ersjournals.com/content/24/135/132.full

39. Gargano G, Braibanti S. Lung recruitment strategy and surfactant in delivery room. Acta Biomed [Internet]. 2014 Jun 20 [cited 2016 Ap 27];85(1):7-10. Available from: https://www.ma ttioli1885journals.com/index.php/actabiomedica/ article/viewFile/3682/2649

40. Speer CP, Sweet DG, Halliday HL. Surfactant therapy: past, present and future. Earl Hum Dev [Internet]. 2013 [cited 2016 Apr 27];89S1:S22 S24. Available from: https://linkinghub.elsevie .com/retrieve/pii/S0378-3782(13)70008-2

41. Rodríguez-Moya VS, Quiroz-Viqueira O, Oliva de Céspedes CM, Díaz-Casañas E. Surfactante exógeno como tratamiento de la atelectasia pulmonar masiva. AMC [Internet]. 2015 Jul-Aug [cited 2016 Apr 27];19(4):374-80. Available from: http://scielo.sld.cu/scielo.php?script=sci_arttext \&pid=S1025-02552015000400009. Spanish.

42. Laughon M, Bose C, Moya F, Aschner J, Donn $\mathrm{SM}$, Morabito $\mathrm{C}$, et al. A pilot randomized, 
controlled trial of later treatment with a peptidecontaining, synthetic surfactant for the prevention of bronchopulmonary dysplasia. Pediatrics [Internet]. 2009 Jan [cited 2011 Aug];123(1):89-96. Available from: http://pediatrics.aappublications .org/content/123/1/89.full

43. Gattinioni L, Carlesso E, Brazzi L, Caironi P. Positive end expiratory pressure. Curr Opin Crit Care. 2010 Feb;16(1):39-44.

44. Pintado MC, de Pablo R. Aplicación individualizada de la presión positiva al final de la espiración en pacientes con síndrome de distrés respiratorio agudo. Med Intensiva [Internet]. 2014 Nov [cited 2016 Jan 12];38(8):498-501. Available from: http://www.sciencedirect.com/science/article/pii/ S0210569113002544. Spanish.

45. Keenan JC, Dries DJ. PEEP titration: new horizons. Respir Care [Internet]. 2013 Sep [cited 2016 Apr 27];58(9):1552-4. Available from: http:// rc.rcjournal.com/content/58/9/1552.short

46. Kesecioglu J, Beale R, Stwart TE, Findlay GP, Rouby JJ, Holzapfel L, et al. Exogenus natural surfactant for treatment of acute lung injury and the acute respiratory distress syndrome. Am J Respir Crit Care Med [Internet]. 2009 Nov 15 [cited 2016 Jan 12];180(10):989-94. Available from: http://www.atsjournals.org/doi/full/10.1164/ rccm.200812-19550C

47. Walsh BK, Daigle B, DiBlasi RM, Restrepo RD; American Association for Respiratory Care. AARC Clinical Practice Guideline. Surfactant Replacement Therapy: 2013. Respir Care [Internet]. 2013 Feb [cited 2016 Jan 12];58(2):367-75. Available from: https://www.researchgate.net/ profile/Brian_Walsh8/publication/235381146_A
ARC_Clinical_Practice_Guideline._Surfactant Replacement_Therapy_2013/links/00b7d529b 741864f01000000.pdf

48. Duffett M, Choong K, Ng V, Randolph A, Cook DJ. Surfactant therapy for acute respiratory failure in children: a systematic review and meta-analysis. Crit Care [Internet]. 2007 Jun 15 [cited 2016 Apr 27];11(3):R66. Available from: http://www .biomedcentral.com/1364-8535/11/R66

49. Hong $X Y$, Kong $X Y$, Zhou GX, Liu YH, Yang XY, Feng ZC. [Effects of pulmonary surfactant in treatment of acute lung injury after cardiac surgery in infants]. Zhonghua $\mathrm{Er} \mathrm{Ke} \mathrm{Za} \mathrm{Zhi} \mathrm{[Inter-}$ net]. 2012 Mar [cited 2016 Jan 12];50(3):193-6. Available from: http://europepmc.org/abstract/ med/22801200. Chinese.

\section{THE AUTHORS}

Valentín S. Rodríguez-Moya, pediatrician specializing in pediatric intensive care with a doctorate in medical sciences. Staff pediatrician at Martín Chang Puga General Teaching Hospital in Camagüey Province, Cuba. At the time of this research, he was assistant professor, Ignacio Agramonte Loynaz Community Teaching Polyclinic, Camagüey, Cuba.

María del Carmen Machado-Lubián, pediatrician specializing in pediatric intensive care, with a master's degree in comprehensive child health, National Hygiene, Epidemiology and Microbiology Institute, Havana, Cuba.
Yinet Barrese-Pérez, pharmacist with a master's degree in clinical pharmacology. Associate researcher, National Clinical Trials Coordinating Center (CENCEC), Havana, Cuba.

Yisel Ávila-Albuerne, pharmacist with a master's degree in pharmacology. Associate researcher, CENCEC, Havana, Cuba.

Rolando Uranga-Piña, mathematician with a master's degree in biostatistics. Associate researcher, CENCEC, Havana, Cuba.

Odalys Blanco-Hidalgo, biochemist with a doctorate in pharmaceutical sciences. Senior researcher, National Center for Agricultural Health (CENSA), San José de las Lajas, Cuba.

Elaine Díaz-Casañas (Corresponding author: elaine.diaz@infomed.sld.cu, elaine@censa.edu .cu), chemical engineer with a doctorate in technical sciences. Senior researcher, CENSA, San José de las Lajas, Cuba.

\section{Submitted: October 17, 2016}

Approved for publication: March 22, 2017

Disclosures: Odalys Blanco-Hidalgo and Elaine Díaz-Casañas work at CENSA, manufacturer of Surfacen.

\section{NeuroCuba 2017 International Congress of Neurology and Neurosurgery}

Sponsor: Cuban Society of Neurology and Neurosurgery

Languages: Spanish, English

Information: Ricardo Hodelin Tablada MD PhD

rht@medired.scu.sld.cu

neurocirugia2@infomed.sld.cu

http://www.neurocuba.com/es/invitation

\section{Main topics:}

- History of neurosciences

- Neuro-ophthalmology

- Endoscopy

- Pediatric neurology and neurosurgery

- Vascular surgery and interventional neuroradiology

- Spinal cord surgery

- Functional neurosurgery and stereotactic surgery

- Radiosurgery

- Neurorehabilitation

- Cranioencephalic and spinal cord trauma

- Nervous system tumors

- Epilepsy

- Cerebrovascular diseases

- Neuromuscular and neurodegenerative diseases

- Nervous system infections 